\title{
The Leadership of Women in Military on Military Organization
}

\author{
Nani Kusmiyati \\ Dinas Pendidikan Angkatan Laut (DISDIKAL) Gedung B3 Cilangkap Jakarta \\ Doctoral Program, Department of Human Resource Management, Jakarta State \\ University \\ Jl. Rawamangun Muka, RT.11/RW.14, Rawamangun, Jakarta Timur, 13220 \\ E-mail: nani1navy@gmail.com
}

Hady Efendy (Corresponding Author)

Titan Mineral Utama

Graha Anabatic 10th Floors, Scientia Boulevard Kav. U2 Summarecon, Tangerang 15811

E-mail: efendy_hady@yahoo.co.id

Received: Sep. 26, 2017 Accepted: Oct. 10, 2017 Online published: Oct. 16, 2017

doi:10.5296/ijhrs.v7i4.11911 URL: https://doi.org/10.5296/ijhrs.v7i4.11911

\begin{abstract}
The rapid development of the globalization era demands that the role of a female soldier within the organization of the Indonesian National Army (TNI) succeeds in touching the historical, cultural, social and political aspects prevailing within the Unitary State of the Republic of Indonesia (NKRI). In accordance with the expectations of R.A. Kartini in fighting for gender equality for woman in Indonesia. In military organizations, TNI women must always be able to balance their role as soldiers, wives and mothers for children. On the other hand as TNI women should be able to carry out its duties and responsibilities as a fortress in maintaining the sovereignty of NKRI. Assignment as a TNI woman must be able to compete with other men of TNI. Equality of degrees causes the TNI women to be given the widest opportunity to occupy important positions in the military, including: Commander of the vessel, pilot, diver and other abilities owned by TNI women. In some cases TNI women may be involved in special assignments, such as: UN forces, social activities in mass health and non-structural TNI assignments. Based on the above description will be explained about
\end{abstract}


the insights relating to the leadership of TNI women in military organizations in general, strategy and implementation of the TNI woman leadership style so that it can deliver to the position in the military organization.

Keywords: leadership, military organization, female soldier, woman emancipation, gender

\section{Background}

\subsection{Introduction}

In the rapidly expanding globalization era, the role of a female soldier within the Indonesian National Army (TNI) organization has touched the historical, cultural, social and political aspects prevailing within the Indonesian state. The presence of women in military institutions in Indonesia demonstrates a form of social appreciation and public recognition of the role of women, especially the TNI women corps in every strata and type of work in Indonesia. Indonesian women succeeded in achieving gender equality for the efforts and efforts of the current generation of women or their predecessors who founded women's organizations in the pluralistic society of Indonesia. Recognition of gender equality of Indonesian women is achieved through the struggle and must always be demonstrated in the active role of every woman from the smallest family environment to the national and international spheres in the form of socio-political roles.

The leadership of women in TNI in particular is militarized, much in talk and become a common issue. This has led to a pro and contra debate against women leaders within a country, although the recognition of basic human rights has increased significantly. This recognition also applies to the rights of women equal to men. The thinking in the past that women do not need to be high school, because in the end will be chalk as well, often used as a tool to justify the act of injustice against women. But in accordance with the development of the era then the woman has a very important role in the TNI environment, according to the jargon that had been used in 1982 TNI anniversary: "We are not roses decorate plants, but jasmine fence of the country.

In the military world, TNI women have had a decent place in career development and placement in an important position parallel to TNI men. For that reason, some TNI women who have career in military can be placed in accordance with their profession and expertise they have: commander of ship, pilot, parachutist, diver and other abilities owned by TNI woman. For those positions or skills it is not as much as a TNI man can sit or control. However, TNI personnel needs more emphasis on TNI men to hold operational positions while TNI women are more placed in staff or hospitals. However, the role of TNI women is very important in military organizations. They are instrumental in non-combat fields that can help smooth the activities of military organizations.

Given the current technological advances and weapons that are so modern today, TNI women are given the opportunity to lead certain areas of the military organization. With the expertise and accuracy of TNI women can complete the tasks well. The culture of the organization in particular and culture in Indonesia generally affects TNI women in their role as leaders. In this paper will be discussed how TNI women lead in positions in military organizations by not ruling out their role in family life as the wife of the mother of her children. 


\subsection{Problem}

Based on the background that has been described above, the authors will summarize the formulation of the background issues of writing "The Leadership of Women in TNI in Military Organizations", as follows:

a. What is the leadership of TNI women in the analysis of gender equality?

b. What is the strategy of TNI woman leadership in military organization to get chance and opportunity in high position in career?

c. How to implement the leadership of TNI women in military organizations especially those who have occupied high positions in their careers?

\subsection{Writing Purpose}

Based on the background and problem formulation in this research, the purpose of this research, as follows:

a. Analyze the leadership of TNI women in gender equality analysis.

b. Analyze the military leadership strategy of TNI women in military organizations in obtaining high positions in their careers.

c. Analyze the implementation of TNI women leadership in military organizations especially those who have occupied high positions in their careers.

\section{Literature Review}

\subsection{Leadership Theory}

Leadership is defined as a process of inspiring others to work more actively in carrying out important activities (Schermerhorn, 1999). But that understanding is often linked to the fundamentals of effective leadership, i.e. as a reference to how a leader or manager uses power to influence the behavior of others. Power is the ability to influence a person to do something as desired (Kanter, 1979). So often leadership or leadership is defined as the ability to influence groups to achieve certain goals (Robbins, 1998).

Furthermore, theories of leadership in the opinion of experts can be defined, as follows:

a. The Greatmen Theory.

Based on the belief that the leader is an extraordinary person, born with innate qualities, destined to lead. Known figures are Napoleon, George Washington, or Martin Luther, who has had a major impact on society (Wart, 2003).

b. The Theory of Nature.

According to Bolden, et al (2003) and Wart (2003), listed a series of traits or qualities associated with existing leadership in abundance and continue to be produced. All the traits that describe some of the attributes of human beings are positive or godly, the passion for life. Emphasis on individual traits (physical, personal, motivation, talent) and skills (communication and ability to influence) that accompany leaders to all leadership tasks. 
c. Behavioral Theory.

This theory concentrates on what leaders actually do on the application of their quality.

Different patterns of behavior are observed and categorized as leadership styles (Bolden et al., 2003).

d. Situational Theory.

This approach sees leadership as specific to situations in which leadership is underway. For example, some situations may require an autocratic style, and while others may need a more participatory approach. According to Papworth (2008) the most effective leadership style is determined by the degree of "preparedness" of leaders and followers.

e. Contingency Theory.

This theory is a refinement from a situational standpoint that focuses on identifying situational variables that most predict the most appropriate or effective leadership style to suit a given situation.

f. Transactional Theory.

This approach emphasizes the importance of the relationship between leader and follower, focusing on the state of mutual benefit, this theory stems from a 'contract' form in which leaders provide things like rewards or recognition in return for the commitment or loyalty of followers.

g. Transformation Theory.

The main concept in this theory is the change and role of leadership in imagining and implementing organizational performance transformation. Emphasis on leaders who make changes in the overall structure, process, or culture (Wart, 2003).

\subsection{Military Organization}

Military organizations in the three armed forces: Army, Navy and Air Force (AD, AL and AU) generally have similarities. However the organizational structure of different Force is tailored to the needs of each organization's Force. Likewise, the policies within the military organization are determined by each force. Position positions for TNI women also have different compositions. TNI women have been given many opportunities to occupy strategic positions in the military tailored to the expertise possessed by the TNI woman.

Although the number of positions offered to TNI women are not as many as TNI men, TNI women are considered to be the much-needed work partners in the organization, since certain positions in military organizations would be more appropriate if led by TNI women

\subsection{Gender Equality Regulation}

The Government's commitment to achieve gender equality and justice has long been written in the constitution of the 1945 Constitution which guarantees and protects human rights without distinction of race, religion, gender or gender. Even in order to achieve gender equality and justice, the President also established the Ministry of Women's Role Affairs (MENMUD UPW) which is the forerunner of the Ministry of Women Empowerment and Child Protection. In 1984, the Government of Indonesia ratified the "women's convention", 
the Convention on the Elimination of All Forms of Discrimination against Women into law no. 7th 1984. In order to continue the struggle to achieve gender equality and justice the Government then issued Presidential Instruction No. 9 of 2000 on Gender Mainstreaming in National Development and Ministry of Home Affairs Decree no. 132 of 2003 on general guidance on the implementation of gender mainstreaming in regional development as a follow up of the Presidential Instruction (Inpres).

The fourth paragraph of the Preamble of the 1945 Constitution which reads "to form a government of the State of Indonesia that protects the entire nation of Indonesia and the entire blood of Indonesia and realize the common prosperity, educate the life of the nation and participate in implementing the world order based on freedom, eternal peace and social justice" has a philosophical meaning The state guarantees everyone's right and is obliged to protect those rights from discriminatory behavior. In addition, the word social justice can also be interpreted that every process and development results must be felt by all Indonesian people both men and women. Therefore, the GCG Bill is philosophically in line with what has been mandated by the Preamble of the 1945 Constitution as the ideals of the nation and the State. With the draft of KKG bill, it is expected that the social responsibility of government, private and public to gender equality and justice will increase.

\subsection{Career Regulation of TNI Women Corps}

In the general provisions that exists concerning the fostering and careers of women TNI against the coaching and assignment, namely:

a. Law of the Republic of Indonesia Number 34 Year 2004 Concerning the Defense Force of Indonesia, among others stated that: (1) Soldiers are citizens who are prepared and armed for state defense tasks to face military threats and armed threats; (2) to serve the interests of the state over regional, ethnic, racial, and religious groups; And (3) The Professional Army, which is a well-trained, educated, well-equipped, non-practicable, non-business, and guaranteed welfare force, and follows the political policies of a country that embraces democratic principles, civil supremacy, human rights, national law provisions, And international law that has been ratified; (4) The main duties as intended shall be by: (a) Military operations for war; (B) Military operations other than war, namely: (B.1). Overcoming armed separatist movements; (B.2). Overcoming armed insurrection; (B.3). Addressing acts of terrorism; (B.4). Securing border areas; (B.5). Securing a strategic national vital object; (B.6). Carry out the task of world peace in accordance with foreign policy; (B.7). Securing the President and Vice President and his family; (B.8). Empower the region of defense and its supporting forces early in accordance with the defense system of the universe; (B.9). Assisting regional government duties; (B.10). To assist the Police of the Republic of Indonesia in the framework of the security and public order stipulated in the law; (B.11). Help secure state guests at the head of state and representatives of foreign governments residing in Indonesia; (B.12). Helping to cope with natural disasters, displacement and humanitarian assistance; (B.13). Helping search and rescue; and (B.14). Assist the government in securing shipping and aviation against piracy, piracy and smuggling. 
b. Government Regulation of the Republic of Indonesia Number 39 Year 2010 concerning Administration of Soldiers of Indonesia National Army, among others, stated that: (1) Women who become Soldiers in undergoing Department of Warriors adjusted to the nature, dignity, and dignity of femininity. (2) Every Soldier is given the rank. (3) The rank according to its nature is distinguished as follows: (2.1). The effective rank assigned to the Soldiers during the Warrior Service and brought the full administrative effect; and (2.2). Special rank consisting of local rank and titular rank.

\section{Result and Discussion}

\subsection{The Leadership of TNI Women in Gender Equality Analysis}

There are two social life differences between men and women, the community environment as the first place for men, while the home environment becomes the first place for women. The thing that causes women harm is the interpretation of their biology so that women are less well known and less competent in custom, so the task of women is only to take care of the children and stay at home. For that reason, the cause of women has little role in the political arena, namely:

a. According to Religious Interpretation. Culturally women are still regarded as being under male leadership, so women generally have no voting rights in decision making and decisions, matters relating to social, political, and economic life.

b. Less Self-Confidence Women (Tjokrominoto, 1996: 31). The development of the women's movement is directed towards one point, namely the domestication of women by putting the woman in the household, as the spousal wife of the husband and mother of the children. This policy makes women apolitical or low political awareness (H. Dian, 2002: 25). So men are more associated with authority in political life in society than household environment.

Rasdiayanah put forward a description of classical discrimination against women (Andi Rasdiana, 1999: 41) that the view that women are more suited to domestic work is also the view that women are more using their feelings than rational, so that women are less suited to the field of work that requires physical labor.

But in the current era of globalization the role of women in Indonesia has been increasingly changing and growing more advanced, seen from the results of research that has been done seems that women in the present have some uniqueness, that is able to play a double role, in addition to his natures as a mother, ladies have endurance which is higher than men. The results show, women are generally more diligent, economical and thrifty and can be trusted to occupy certain important positions. But why women in reality are marginalized, marginalized, subordinated, degraded, powerless and even exploited in many sectors of life, especially in politics, in the process of decision making and public policy determination. If analyzed, there are two factors that cause the condition, namely: internal factors of women and external factors. As described below:

1) Internal factors, namely the quality of women themselves. Despite the large number of women, they are potentially less likely to take advantage of opportunities and 
opportunities to improve their self-qualities through increased knowledge of knowledge, self-control, communication and actualization.

2) External factors, namely factors that originate from outside women, such as male domination to remain a leader. The emergence of interpretations of religious teachings that are contrary to the principle of justice and equality of human creation by the Khaliq. Such reality has positioned women in a lack of empowerment as well as a lack of opportunities for women to be more existence.

\subsection{Strategy of TNI Women's Leadership in Military Organization in Occupying High Offices}

The role of a female soldier within a military organization has touched upon the historical, cultural, social and political aspects prevailing within the Indonesian state. Indonesian women succeeded in achieving gender equality for the efforts and efforts of the current generation of women and their predecessors who founded women's organizations within the pluralistic environment of Indonesian society. The historical basis of the role of Indonesian women is preceded by R.A. Kartini. His initiative and thought in that era shows that women in Indonesia are able to equate with men. Literacy reading and correspondence R.A. Kartini, provides a broad insight and knowledge of the progress of European women's thinking. Through the exchange of thoughts and opinions with the friends of the pen in the Netherlands, to elevate the status of new Indonesian women to fruition when the effort to establish a women's school has obtained permission from the husband, K.R.M. Raden Ario Singgih Djojo Adhiningrat, Rembang Regent in 1903. Inspiration of R.A. Kartini and his book collection gained the attention of Indonesian society and the world so as to lift the dignity of women to be equal with men in Indonesia. And it is this spirit which is exhaled to the women soldiers in the Indonesian military to play a role in a male-dominated organization with all aspects of its masculinity.

With the echoes of women's emancipation and gender equality that developed today, the existence of women in the military world is able to influence the culture of the general culture of Indonesian society. The view that women must follow their nature to do domestic work begins to fade. Containing, childbirth, breastfeeding up to child rearing is a long-culturally domestic work done as "the only" work of an adult woman. It is increasingly closed with the flow of globalization that demands every human being, male and female, to have a decent job and life for the welfare of his family. Indonesian women with intellectual ability are able to work and earn in any form of social and work environment, including the extreme work environment of the military though.

Gender equality that has been born in military organization in Indonesia, will still form TNI woman cannot be separated from his nature as a mother and wife. Social pressure tends to corner women, especially those with careers and decent work, when problems occur in their households. Failure to foster husband-wife harmony or mistakes in educating children, never charged socially to the husband who is predicated as the breadwinner for the family. The thickness of this patrilineal culture is reinforced by religious dogma and the legacy of customs prevailing in most parts of the archipelago. This requires the women of TNI to always be able to balance its role as a soldier, companion of husband and mother for the next 
generation. Not only able to compete with the men within the TNI itself, but also acts as a wife and mother who carries out family management so as to dismiss the social pressure of the surrounding environment. From this socio-cultural condition, gender equality that the TNI women want to achieve is not necessarily obtained from senior reputation, the recommendation of the superior and the background of his predecessor. However, based on hard work and real work that begins from the family environment, community and professional environment.

To gain widespread public recognition and appreciation, the role of TNI women has not ceased to the scope of military institutions. There are 13 ministries and non-ministerial government agencies (K / LPNK) that can be a continuation of careers for the TNI Women Corps at central government level. Strategic positions at the level of government agencies are not separated from the flow of political arena that can always affect the dislocation of positions when not meeting the competencies outlined. Similarly, high-level filling at these levels demands qualified, educational, track record and responsible individual integrity. The placement of 9 TNI women as high officers at K / LPNK level proves that the role of the TNI women's corps has gained political recognition at the national level. Expectations on the aspect of the intellect, professionalism and character of women soldiers on such a political level will not distinguish the background of work, education and so on, including sex. Everything is treated equally.

This is where Indonesian women must understand the notion of gender equality, equal treatment conditions between men and women in the eyes of law and quality of life is just the outer layer of the meaning of gender equality. Because in it there is also a long history of Indonesian women's struggle to gain the recognition of equality in that era against the culture of patriarchal culture wrapped tightly with religious norms. Therefore, the recognition of gender equality is the work of multi-woman women in Indonesia ranging from family to government level. And this is a predicate that is always answered with real work and effort that never stops. Not just to earn a living and profession but also to build the nation equally. The role of Indonesian women is needed to improve the wheels of the country's economy. The proper HR management, active involvement of Indonesian women will increase the workforce. Not just domestic employment but a public job that really enhances the dignity of women to be equal to men.

\subsection{Implementation of TNI Women's Leadership in Military Organizations in High Positions}

The TNI women officer in the military is a leader, a TNI women officer is well-prepared, especially with regard to military science, skills and skills in leadership science, and how to interact socially with fellow male officers, with leadership and with the community. To be a leader in a military environment is not easy, nor can it be obtained instantaneously, but through a long process, by continuing to learn and practice. For that reason, in the present era, TNI women will have the same status as men and in some military activities the TNI has placed officers from the TNI women corps to be involved and given the opportunity to become leaders in military assignments and operations. The activities involving TNI women today can be seen below, among others: 
a. UN troop dispatch. Several times the contingent of UN troops involving the TNI, also involved TNI women in non-combat strata, but also in Head Quarters staff and medical community.

b. Natural Disaster Management. In Disaster Management activities in Padang 2016 ago, on the consideration of staff and ethnographic approach. The TNI commander has assigned a TNI high officer from the TNI women corps to lead the medical team in the handling of victims of natural disasters, especially the victims of medical care, the victims of psychic trauma and elderly victims. Cooperative attitude shown in the team's supervision is based on discipline, obedience and humanitarian priority.

c. Social activities. In the events of 212 in Jakarta some time ago, on the consideration of staff and ethnographic approach. The TNI commander also commissioned the first admiral of TNI Drg. Nora, one of the TNI commander level 2 expert staff to lead the TNI women detachment from 3 "matra" Women Army Corps (Kowad / TNI AD), Women of Navy Corps (Kowal / TNI AL) and Women of Air Force (Wara / TNI AU) mingling with masses conducting mass activities in key strategic areas (Istana Negara and Monument of the National Monument). Quite effective and empathetic amidst the sun and heavy rain; the appeal to be orderly and not anarchic may be obeyed. The assertiveness shown in the detachment is based on discipline, obedience and solidarity prioritizing safety and humanity.

d. Assignment outside the Military Organization. There are several High Officers of TNI Women (Army, Navy and Air Force) who are given the task of holding positions under the ministry or other positions outside the military organizational structure. This suggests that gender equality for TNI women is indeed being implemented within TNI environments, where TNI women will be given the widest possible opportunity for key positions.

From the above description, until now there has been no strict and detailed regulation for gender equality that can be implemented in accordance with existing regulations on guidance and assignment in TNI that can be occupied / held by TNI women. On the other hand, the capability of skill and competence has been owned by TNI women to be able to take part in professionally and proportionally professionally fielded by not violating their natures, dignity, and dignity.

To that end, the TNI finally allowed women to enter the TNI academy (Military Academy, Navy Academy, and Air Force Academy) for the following reasons: First, the time was close to when the western countries opened up all their military roles to women, including Australia (2011), USA and English (2013); Second, former UN Secretary-General Ban $\mathrm{Ki}$-moon visited Indonesia to ask for an increase in the deployment of peacekeepers, especially women (Ki-Moon, 2012). Although changes have occurred, there is no guarantee that members of the TNI women will get a better career promotion than before, or be as good as Police Women (Polwan). When compared to Polwan who had occupied the position as Banten police chief in middle 2008-2010, there has never been a member of TNI women who are trusted to hold leadership positions. This shows that the TNI has not dared to provide an opportunity for women to lead operational positions within the TNI, in contrast to the "brave" armed forces in the Philippines appointing a Women's Captain Fleet. 


\section{Conclusion}

TNI women today have some peculiarities that is able to play a double role, in addition to its nature as a housewife, women have higher resilience than men. The results showed, women in general women more diligent, economical and efficient and reliable to occupy certain important positions. The thickness of this patrilineal culture is reinforced by religious dogma and the legacy of customs prevailing in most parts of the archipelago. This requires that TNI women not only compete with men within the TNI itself, but also serve as wives and mothers who carry out family management so as to ward off social pressure from the surrounding environment. In the present time, TNI women have the same status as men and in some military activities the TNI has placed officers from the TNI Women Corps to be involved and given the opportunity to become leaders in military assignments and operations.

\section{References}

Dian, H. (2002). Perspektif tentang Perubahan Sosial. Jakarta: PT. Rineka Cipta.

Haslam, S. A., Reicher, S. D., \& Platow, M. J. (2011). The New Psychology of Leadership, Identity, Influence, and Power. Psychology Press, Taylor and Francis Group, Hove and New York.

Kanter, R. M. (1979). Power Failure in Management Circuits. Harvard Business Review, 47, $65-75$.

Peraturan Pemerintah Republik Indonesia Nomor 39 Tahun 2010 Tentang Administrasi Prajurit Tentara Nasional Indonesia.

Rasdiana, A. (1999). Seni Dalam Ritual Agama. Yogyakarta: Yayasan untuk Indonesia.

Robbins, S. P. (1998). Organizational Behavior: Concepts, Controversies, \& Application. 8th Ed. Prentice-Hall International, Inc., New Jersey.

Schermerhorn, J. R. Jr. (1999). Management. John Wiley \& Sons, Inc., New York.

Tannen, D. (2003). Communication Matters: He Said/ She Said: Women, Men and Language. Georgetown University.

Tjokrominoto. (1996). Negara dan Nasionalime Indonesia. Jakartata: Gramedia.

Undang-Undang Republik Indonesia Nomor 34 Tahun 2004 Tentang Tentara Nasional Indonesia.

\section{Copyright Disclaimer}

Copyright for this article is retained by the author(s), with first publication rights granted to the journal.

This is an open-access article distributed under the terms and conditions of the Creative Commons Attribution license (http://creativecommons.org/licenses/by/4.0/). 